\title{
Identification of agricultural information needs and development of suitable information flow model for effective dissemination of agricultural information through web and mobile applications
}

\author{
J. Phani Vardhan, N.T. Krishna Kishore and Y. Prabhavathi
}

Received : 07.02.2020; Revised : 03.03.2020; Accepted : 18.03.2020

\begin{abstract}
Farmers need information at all stages from crop production to post-harvest management. With the advent of ICT drastic changes in agricultural information dissemination is been seen. To know the information and media that famers prefer a study was conducted in Krishna and Guntur districts of Andhra Pradesh. Purposive cum random sampling was used to select sample and data was collected using schedules. Factor analysis technique was used to reduce the number of variables to eight. Video and text messages were major media preferences of farmers. Model deciphering the flow of information through IT enabled devices was figured followed by scope and strategies for penetration of ICT to farmers were also suggested.
\end{abstract}

KEY WORDS : ICT, Dissemination, Information, Web, Mobile

How to cite this paper : Vardhan, J. Phani, Kishore, N.T. Krishna and Prabhavathi, Y. (2020). Identification of agricultural information needs and development of suitable information flow model for effective dissemination of agricultural information through web and mobile applications . Internat. J. Com. \& Bus. Manage, 13(1) : 9-15, DOI: 10.15740/HAS/IJCBM/13.1/9-15. Copyright@ 2020: Hind AgriHorticultural Society.

\section{MEMBERS OF THE RESEARCH FORUM}

Correspondence to:

J. Phani Vardhan, Institute of Agribusiness Management, Acharya

N.G. Ranga Agricultural University, Guntur (A.P.) India

E-mail: jpvardhan.3@gmail.com

\section{Authors' affiliations:}

N.T. Krishna Kishore and Y. Prabhavathi, Institute of Agribusiness Management, Acharya N.G. Ranga Agricultural University, Guntur (A.P.) India 